\title{
Stress and coping strategies of medical students during their first clinical practice - a pilot study
}

\section{Stres i radzenie sobie ze stresem studentów kierunków medycznych podczas pierwszych zajęć klinicznych - badania wstępne}

\author{
Iwona Bodys-Cupak로 Aneta Grochowska², Joanna Zalewska-Puchałaํ, Anna Majda \\ 'Faculty of Health Sciences, Jagiellonian University Medical College, Krakow, Poland \\ Head of the Faculty: Prof. dr hab. Tomasz Brzostek \\ ${ }^{2}$ Faculty of Health Care, Department of Nursing, The State Higher Vocational School, Tarnow, Poland \\ Head of the Department: Zbigniew Szyguła PhD
}

Key words: stress, coping strategies, student, sense of self-efficacy.

Słowa kluczowe: stres, strategie radzenia sobie ze stresem, student, poczucie skuteczności.

\begin{abstract}
Introduction: The medical profession is acknowledged as one of the most stressful. The time devoted to acquire knowledge and practical skills is a source of stress for students, but also an opportunity to learn how to deal with it. Aim of the research: To assess how medical students deal with stress during their first clinical practice.

Material and methods: The study was conducted in a group of 526 students of: nursing, physiotherapy, medical rescue, and obstetrics at a university. The research tools included: an original questionnaire, the Perceived Stress Scale, and the Stress Management Inventory. The dependence between variables was established using the Spearman's rank correlation. A significance level of $\alpha=0.05$ was assumed in the tests.

Results: Almost half of the students experienced high levels of stress, and more than half of them manifested high levels of self-efficacy. The participants dealt with difficult situations mainly by active coping, planning, and seeking instrumental support. The paramedics and the midwives more often turned to active coping than did the physiotherapists. Younger people were more inclined to choose strategies associated with seeking support (rho $=-0.134, p=0.001$ ). It was shown that strategies of managing difficult situations based on helplessness were more often followed by older people (rho $=0.126$, $p=0.002$ ). The greater sense of self-efficacy in the participants, the more often they chose active stress coping strategies. Conclusions: Active stress management strategies should be developed in students also to strengthen their sense of selfefficacy.
\end{abstract}

\section{Streszczenie}

Wprowadzenie: Wykonywanie zawodów medycznych uznawane jest za jedno z najbardziej stresujących zajęć. Czas poświęcony na zdobywanie wiedzy i umiejętności praktycznych jest również źródłem stresu dla studentów kierunków medycznych, a także okazją do nauczenia się, jak sobie z nim radzić.

Cel pracy: Ocena, w jaki sposób studenci kierunków medycznych radzą sobie ze stresem podczas pierwszej praktyki klinicznej.

Materiał i metody: Badanie przeprowadzono w grupie 526 studentów: pielęgniarstwa, fizjoterapii, ratownictwa medycznego i położnictwa. Narzędzia badawcze obejmowały: autorski kwestionariusz ankiety, Skalę odczuwanego stresu i Inwentarz radzenia sobie ze stresem. Zależność między zmiennymi ustalono za pomocą korelacji rang Spearmana. W testach przyjęto poziom istotności $\alpha=0,05$.

Wyniki: Prawie połowa studentów doświadczyła wysokiego poziomu stresu, ponad połowa z nich miała wysoki poziom poczucia własnej skuteczności. Studenci radzili sobie ze stresem poprzez aktywne zarządzanie, planowanie i poszukiwanie instrumentalnego wsparcia. Ratownicy medyczni i położne częściej podejmowali aktywne formy radzenia sobie niż fizjoterapeuci. Osoby młodsze były bardziej skłonne wybierać strategie związane z poszukiwaniem wsparcia $($ rho $=-0,134$, $p=0,001$ ). Wykazano, że osoby starsze częściej stosowały strategie radzenia sobie z trudnymi sytuacjami oparte na bezradności (rho = 0,126, $p=0,002$ ). Im większe było poczucie własnej skuteczności u uczestników, tym częściej wybierali oni strategie aktywnego radzenia sobie ze stresem.

Wnioski: U studentów należy rozwijać aktywne strategie radzenia sobie ze stresem, a także wzmacniać ich poczucie własnej skuteczności. 


\section{Introduction}

The medical profession is acknowledged as one of the most stressful. People preparing to engage in the medical profession are affected by especially strong and abundant stress factors. The reason behind this is emotional engagement in contact with patients and responsibility for human health and life. Predispositions for performing those professions are associated with relevant personal skills and an ability to deal with stress. The first contact with one's future profession in the clinical environment is very important for students of nursing, obstetrics, medical rescue, or physiotherapy. It takes place during practical classes, which are carried out in healthcare facilities and are aimed at optimising practical and social skills. The students are perfecting such skills as: instrumental activities, interpersonal communication, cooperation with the therapeutic team, organisation of work at the ward, and implementation of tasks of therapeutic team members. Students in clinical practice are subjected to not just the academic stressors but to the same kind of stress that professionals suffer from. During these classes students realise that their chosen profession involves stress. A lot of research has confirmed the occurrence of stressful situations in the course of education of students of medical professions [1-5]. The major source of stress for the students are the practical classes in a clinical environment. That is where they have to deal with difficulties with interpersonal interactions and lack of knowledge, insecurity in the scope of nursing skills, and taking care of dying patients. Stress also results from actions undertaken in difficult and rapidly changing situations. Experiencing strong stress by the students may impact their professional future. The emotions experienced in the clinical environment are known as related to an academic adaptation and success and also to the student health and well-being. A little dose of stress is motivational, however too high stress levels disturbs learning processes The impact of stress is different for individuals depending on whether their response to stressors is negative or positive and how they recognise their stress [4,6-8]. Dealing with stress is significant in the process of adaptation to stressful situations. Coping strategies are the specific efforts, both behavioural and psychological, that individuals employ to master, tolerate, reduce, or minimise stressful events. Active coping is considered a better way to deal with stress, while avoidance coping is considered as a psychological risk factor for adverse responses to stressful life events. The research showed that students apply various combinations of dealing with difficult situations, from avoidance behaviours to problem solving [7, 9-14]. Okumura et al. claimed that strategies may depend on individual stress tolerance [15]. In difficult situations students may have limited ability to cope effectively with stress. Effective stress management is an important skill for students. Perfecting this skill allows optimum efficiency in the future. Reducing the incidence of stress and burnout seems to be possible by promoting strategies that focus on personal engagement, extracurricular activities, positive reinterpretation and expression of emotion, student-led mentorship programs, evaluation systems, career counselling, and life coaching.

\section{Aim of the research}

The aim of this study was to assess stress levels, stress coping styles, and sense of self-efficacy in medical students during their first clinical practice. A stronger sense of self-efficacy and activation of mechanisms of coping with difficult situations may favour better results and satisfaction with the chosen profession. Developing and improving one's professional identity may prove helpful for medical students in managing role stress.

\section{Material and methods}

A cross-sectional descriptive study was conducted in Jagiellonian University and the State Higher Vocational School in Tarnow in 2017/2018. The research was carried out using the diagnostic questionnaire method, estimation, and the surveying technique.

The study involved 526 subjects who were firstyear undergraduates of nursing, obstetrics, physiotherapy, and emergency medicine. The fieldwork was carried out after the students had completed the first block of practical training classes (at the last meeting). The students were enrolled in the study if they: 1) were studying for an undergraduate degree, 2) were in the first year of studies, 3) had completed the practical classes (no less than $80 \mathrm{~h}$ ), and 4) had given informed consent to participate in the study. Students were given the opportunity to express their independent opinions without any conflict of interest.

The research tools included: an original questionnaire, the Perceived Stress Scale by S. Cohen, T. Kamarck, and R. Mermelstein adapted by Z. Juczyński and N. Ogińska-Bulik; an inventory to measure coping with stress by S. Charles Carver adapted by Z. Juczyński and N. Ogińska-Bulik; and the Generalised Self-Efficacy Scale by R. Schwarzer, M. Jerusalem, and Z. Juczyński [16].

The author's questionnaire consisted of questions about sociodemographic data.

The Perceived Stress Scale (PSS-10) by S. Cohen, T. Kamarck, and R. Mermelstein was used to assess the severity of the stress related to respondents' own life situation during the last month. It contained 10 questions about subjective feelings associated with personal issues and events. For each question, the respondent answered using a five-point scale from "never" - 0, to "very often" -4 . The overall score of 
the scale, being the sum of points, had a theoretical distribution ranging from 0 to 40 . After converting into standardised units, the results within 1-4 sten scores were treated as low, 5-6 as average, and 7-10 as high. Cronbach's $\alpha$ for the scale is 0.86 [16].

The inventory to measure coping with stress (Mini-COPE) was used to assess typical reactions to, and perceptions of, stress in stressful situations. The inventory comprised 28 statements included in 14 strategies of stress management, which were divided into seven factors: active management, including: active management, planning, and positive revaluation; seeking support, including: seeking emotional support and seeking instrumental support; helplessness, including use of psychoactive substances, ceasing activity, and self-accusation; and avoidance behaviours, including: getting engaged in another activity, denial, and venting off. Turning to religion, acceptance, and humour were treated as independent factors. For each claim, the participant had to choose one of four answers, from 'I almost never do that' to 'I almost always do that'. In the analysis of results problem-focused strategies were also distinguished, including: active management, planning, seeking instrumental support, and emotion-focused strategies, i.e. seeking emotional support, turning to religion, and denial.

The Generalised Self-Efficacy Scale (GSES) measured the strength of the individual's overall belief in their effectiveness in coping with difficult situations and obstacles. It consisted of 10 statements relating to different personal characteristics, which the respondent marked as true or false in their particular case. The theoretical range of the scale was 0 to 40 points. Higher scores corresponded to a higher sense of selfefficacy. The maximum number of points it was possible to obtain was within the numerical range 30-40 points, which indicated a high sense of self-efficacy, between 25-29 meant an average level, and between 10-24 points meant a low level. The scale has a moderately high criterion validity and reliability with Cronbach's alpha coefficient for the scale at 0.85 [16].

In total 642 questionnaires were distributed, of which 529 were returned, and three were rejected due to numerous shortcomings in responses. Therefore, 526 questionnaires were left for analysis and statistical work. Questionnaires received from respondents were evaluated individually and checked for completeness. Data was then coded, entered into the database, and processed using IBM SPSS Statistics 20 for Windows.

Quantitative variables were described through arithmetic mean, standard deviation, and range.

Differences between variables were tested using the chi-square independence test, Kruskal-Wallis test, and Spearman's rank correlation. The adopted level of significance was $\alpha=0.05$.
The study was approved by the Jagiellonian University Medical College Bioethics Committee (approval no. 122.6120.193.2015).

The authors' permissions were granted for the use of all research tools. The students were informed about both the confidentiality and anonymity of the research, and that participation was voluntary, and they could refuse/withdraw from the study at any time during the study.

\section{Results}

More than half of the 562 students who participated in the study ( $n=322$, i.e. $57.30 \%)$ were nurses. Significantly less numerous groups were those of physiotherapists ( $n=100$, i.e. $17.19 \%)$, midwives $(n=80$, i.e. $14.23 \%)$, and paramedics $(n=60$, i.e. $10.68 \%)$.

The majority of participants $(n=494$, i.e. $87.90 \%)$ were women, and $12.10 \%$ of participants $(n=68)$ were men. The midwives group consisted exclusively of women. $93.17 \%(n=300)$ of nurses were women, and in the physiotherapists group $84 \%(n=84)$ of participants were women. Only in the case of paramedics was the percentage of women and men equal. Differences in sex distribution in particular groups were statistically significant $\left(\chi^{2}=101.89 ; \mathrm{d} f=3 ; p<0.0001\right)$.

The average age of the participants was $20.91 \pm 2.04$ years. The youngest participant was 19 years old and the oldest was 35 . Half of the participants were below 20 years old.

Most of the participants ( $n=242$, i.e. $43.06 \%)$ were 20 years old. $19.40 \%$ of participants $(n=109)$, were 21 years old, $13.70 \%(n=77)-19$ years old, and $11.39 \%$ $(n=64)-22$ years old. Over $3 / 4$ of participants (76.16\%) were below 22 years old.

The average age in the group of nurses was 20.89 \pm 2.47 years, and the age range was $19-35$ years; the average age in the group of midwives was $20.98 \pm 1.42$ years - the youngest one was 19 years old, and the eldest was 26 years old. The average age in the group of paramedics was $20.92 \pm 1.14$ years, and the age range was 20-25 years. In the group of physiotherapists, the average age was $20.91 \pm 1.20$ years. The youngest physiotherapist was 19 years old, and the eldest one was 28 years old. Differences in age distribution in particular groups were not statistically significant $\left(\chi^{2}=22.55\right.$; $\mathrm{d} f=3 ; p<0.0001$ ).

It was shown that in $21.00 \%$ of participants $(n=118)$ the level of perceived stress was low. The average stress level was experienced by $29.18 \%$ of participants $(n=164)$. Almost half of the participants $(n=280$, i.e. $49.82 \%$ ) showed a high level of perceived stress (Figure 1).

It was shown that a high level of stress was more often experienced by women $(51.42 \%)$ than by men $(38.24 \%)$. In the male group the level of experienced stress was more often average $(38.24 \%)$ than in the female group (27.94\%). However, discovered differences 
between the age and level of perceived stress were not statistically significant ( $p=0.1057$ ) (Figure 2).

The average age (20.62 y.o.) of people with low stress level was lower than the average age (21.01 y.o.) of people with average or high (20.97 y.o.) stress levels. However, the differences between the age and level of perceived stress were not statistically significant $(p=0.1313)$.

Slight statistical differences were shown between the levels of perceived stress among the groups participating in the study. The differences in question regarded stress perception at the average level in the group of midwives $(22.5 \%)$ and physiotherapists (41.00\%) (Table 1).

It was shown that $9.79 \%$ of the participants $(n=55)$ displayed low levels of self-efficacy. In the case of $35.05 \%$ of people $(n=197)$ the level of selfefficacy was average. In over half of the participants $(n=310$, i.e. $55.16 \%)$ the sense of self-efficacy was high.

People with average level of self-efficacy were more frequent among women than among men (36.03\%). In the male group, there were insignificantly more people with low level of self-efficacy (14.71\%). The discovered differences were not statistically significant ( $p=0.2126$ ) (Figure 3).

The average age of people experiencing low level of self-efficacy was insignificantly higher (21.29 y.o.) than the average age of people with average (20.75 y.o.) or high (20.94 y.o.) level of self-efficacy. The discovered differences were not statistically significant $(p=0.0752)$.

The level of self-efficacy was not significantly different between nurses, midwives, paramedics, and physiotherapists $(p=0.1324)$.

On the basis of analysis of results of the Mini COPE scale, it was shown that in difficult situations the participants most often turned to active management $(2.06 \pm 0.63)$. A slightly lower number of participants chose strategies based on planning $(1.98 \pm 0.70)$, seeking instrumental support (1.93 \pm 0.75$)$, seeking emotional support (1.92 \pm 0.74$)$, or seeking acceptance (1.81 \pm 0.71$)$. Less popular, but also frequently chosen, management strategies included: engagement in another activity $(1.69 \pm 0.76)$ and positive revaluation $(1.68 \pm 0.72)$. To a lesser extent (significantly below the

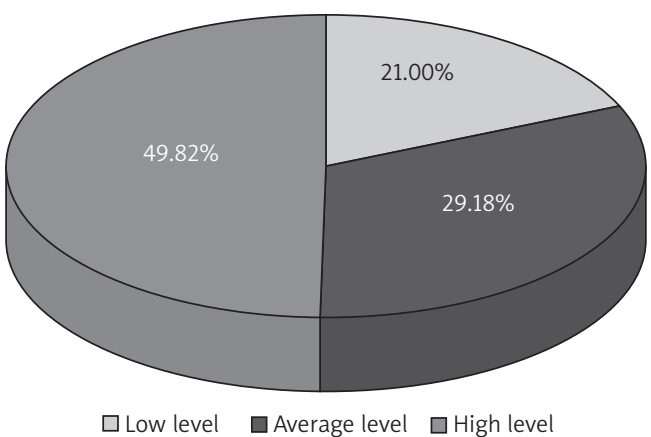

Figure 1. Stress levels in the participants

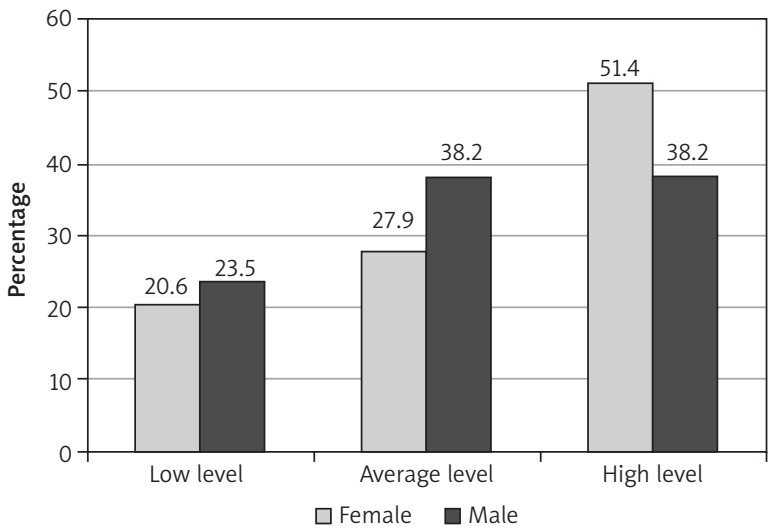

Figure 2. Stress levels and sex of the participants

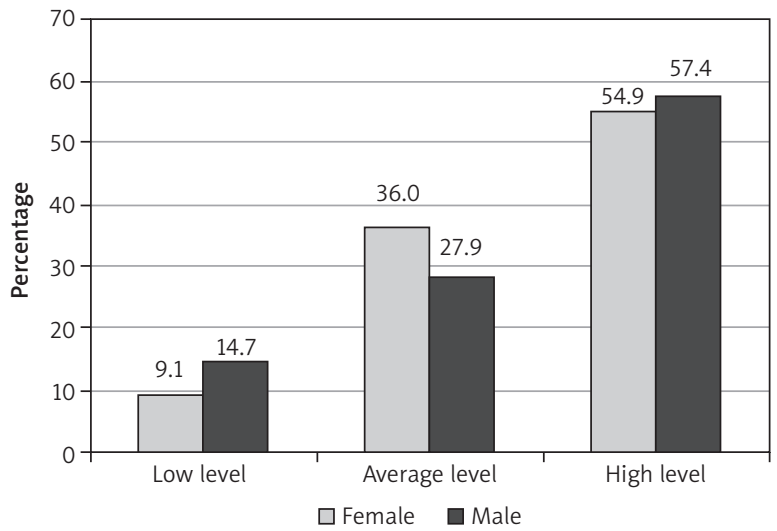

Figure 3. Self-efficacy levels and sex of the participants

Table 1. Stress levels and the group of participants $(n=526)$

\begin{tabular}{|c|c|c|c|c|c|c|c|c|}
\hline \multirow[t]{3}{*}{ Parameter } & \multicolumn{8}{|c|}{ Student group } \\
\hline & \multicolumn{2}{|c|}{ Nursing } & \multicolumn{2}{|c|}{ Obstetrics } & \multicolumn{2}{|c|}{ Medical rescue } & \multicolumn{2}{|c|}{ Physiotherapy } \\
\hline & $N$ & $\%$ & $N$ & $\%$ & $N$ & $\%$ & $N$ & $\%$ \\
\hline Low level & 73 & 22.67 & 15 & 18.75 & 17 & 28.33 & 13 & 13.00 \\
\hline Average level & 89 & 27.64 & 18 & 22.50 & 16 & 26.67 & 41 & 41.00 \\
\hline High level & 160 & 49.69 & 47 & 58.75 & 27 & 45.00 & 46 & 46.00 \\
\hline$P$-value & \multicolumn{8}{|c|}{0.0362} \\
\hline
\end{tabular}


Table 2. Stress coping strategies and sex of the participants $(n=526)$

\begin{tabular}{|lccccccc|}
\hline \multirow{2}{*}{ Sex/MiniCOPE } & \multicolumn{2}{c}{ Female } & \multicolumn{2}{c}{ Male } & \multicolumn{2}{c}{ Total } & \multirow{2}{*}{ P-value } \\
\cline { 2 - 6 } & Mean & SD & Mean & SD & Mean & SD & \\
Active management & 2.07 & 0.62 & 2.04 & 0.70 & 2.06 & 0.63 & 0.8016 \\
Planning & 1.98 & 0.70 & 1.96 & 0.66 & 1.98 & 0.70 & 0.7405 \\
Positive revaluation & 1.69 & 0.72 & 1.64 & 0.73 & 1.68 & 0.72 & 0.5707 \\
Acceptance & 1.83 & 0.71 & 1.63 & 0.70 & 1.81 & 0.71 & 0.0278 \\
Humour & 1.07 & 0.72 & 1.21 & 0.76 & 1.09 & 0.73 & 0.2164 \\
Turning to religion & 1.34 & 0.96 & 1.10 & 0.88 & 1.31 & 0.95 & 0.0517 \\
Seeking emotional support & 1.97 & 0.73 & 1.57 & 0.74 & 1.92 & 0.74 & 0.0001 \\
Seeking instrumental support & 1.98 & 0.75 & 1.57 & 0.68 & 1.93 & 0.75 & $<0.0001$ \\
Getting engaged in another activity & 1.71 & 0.74 & 1.50 & 0.88 & 1.69 & 0.76 & 0.0502 \\
Denial & 0.88 & 0.77 & 0.86 & 0.85 & 0.88 & 0.78 & 0.6596 \\
Venting off & 1.46 & 0.72 & 1.28 & 0.77 & 1.44 & 0.73 & 0.0561 \\
Use of psychoactive substances & 0.51 & 0.72 & 0.88 & 0.94 & 0.56 & 0.76 & 0.0015 \\
Ceasing activity & 0.84 & 0.72 & 1.04 & 0.73 & 0.87 & 0.72 & 0.0302 \\
Self-accusation & 1.45 & 0.80 & 1.33 & 0.72 & 1.44 & 0.79 & 0.3546 \\
\hline
\end{tabular}

$S D-$ standard deviation, $p$ - level of statistical significance $p=0.05$.

central value on the 0 -3-point scale, i.e. 1.5 points) the following strategies were selected: venting off $(1.44$ $\pm 0.73)$, self-accusation $(1.44 \pm 0.79)$, turning to religion $(1.31 \pm 0.95)$. To a limited extent, the participants were inclined to choose strategies associated with humour (1.09 \pm 0.73$)$, denial $(0.88 \pm 0.78)$, refraining $(0.87$ $\pm 0.72)$, or using psychoactive substances $(0.56 \pm 0.76)$.

Significant differences were shown between the sex of the participants and choice of strategy of dealing with difficult situations. It was shown that women more often than men actually chose strategies based on acceptance (1.83), and seeking emotional or instrumental support (respectively, 1.97 and 1.98). In difficult situations, men more often reached for psychoactive substances (0.88) or ceased their activity (1.04) (Table 2).

The age of the participants significantly affected their choice of seeking emotional and instrumental support and drug use or ceasing activity. It was shown that older people were less inclined to seek emotional and instrumental support (respectively, rho = -0.116 and rho $=-0.118$ ), while in difficult situations they more often reached for psychoactive substances $($ rho $=-0.144)$ or refrained from their activity (rho $=$ -0.108 ) (Table 3).

Significant statistical differences were shown between groups of participants and the choice of strategy of dealing with difficult situations. It was shown that paramedics (2.23) and midwives (2.19) more often actively managed difficult situations than physiotherapists (1.90). Similar differences occurred in case of choice of the planning strategy. The choice of a humour strategy was mostly preferred by physiotherapists (1.44) than by other participating groups. Paramedics were least inclined (0.93) to turn to religion. Physiotherapists were less inclined (1.73) to seek emotional support than nurses and midwives. Seeking instrumental support was slightly more often chosen by nurses and midwives. Physiotherapists chose denial more often (1.33) than other participants. This was also the group that more often reached for psychoactive substances (1.00) or refrained from activity (1.35) (Table 4).

It was shown that strategies of managing difficult situations based on helplessness were more often followed by older people (rho $=0.126, p=0.002)$ (Figure 4$)$.

Younger people were more inclined to choose strategies associated with seeking support (rho = $-0.134, p=0.001$ ) (Figure 5).

The analysis of our own research allowed us to conclude that active management in difficult situations was the least selected by physiotherapists (1.78). This group more often than other groups displayed avoidance behaviours (1.48) and humour (1.44), and also was most frequently helpless (1.27). In difficult situations, midwives and nurses most often sought support (respectively, 2.05 and 1.97). Paramedics were the least inclined (0.93) to turn to religion (Table 5).

Significant statistical differences were shown between the stress levels and choice of strategy of dealing with difficult situations. Moreover, it was concluded that higher stress level is associated with increase 
in interest in strategies based on denial, venting off, using psychoactive substances, refraining, and selfaccusation. People with low results in experienced stress more often than people with high results in stressful situations applied strategies based on active management, positive revaluation, and acceptance (Table 6).

The level of self-efficacy significantly affected the choice of strategy for managing difficult situations by the participants. The greater the sense of self-efficacy in the participants, the more often they chose active stress management strategies, planning, positive revaluation, and acceptance. The lower the sense of selfefficacy in the participants, the more often they chose active stress management strategies, planning, positive revaluation, and acceptance. Participants with low or average results in the GSES scale more often chose turning to religion, as compared to people with high levels of self-efficacy (Table 7).

\section{Discussion}

Stress is present in the entire formation period, and developing stress management skills is very important. Effective stress management allows one not only to reduce the experience of stress, but also to effectively cope with the environment in which professional competence is developed.

It was shown that stress is present in all the aspects of formation of medical students $[8,14,17]$. Almost half of the first-year students participating in our own research experienced intense stress. Similar conclusions were reached by Sun et al. and Bodys-Cupak et al. [18, 19]. However, the results of research conducted on Norwegian students showed that only one third of the participants experienced high or average stress levels [20]. Our own studies, however, showed that higher levels of stress were experienced by older students. Midwives and physiotherapists more often experienced average stress levels than other participating groups. Higher stress levels were experienced by women than by men. Similar results were obtained by other researchers [5, 17, 21, 22].

Some of the most common coping strategies identified by students include: family, social and spiritual support, exercising, problem solving, transference, avoidance, denial as well as smoking, drugs and alcohol $[4,9]$.

Our own research showed that students most often applied active management, planning, seeking instrumental and emotional support, and acceptance and least frequently turned to psychoactive substances. Women more often than men dealt with the situation by acceptance and seeking support. Men more often than women and older people more than young chose psychoactive substances or ceasing activity. It was shown that strategies of managing difficult situations based on helplessness were more often followed
Table 3. Stress management strategies and age of the participants $(n=526)$

\begin{tabular}{|c|c|c|}
\hline \multicolumn{2}{|l|}{ Strategies - stress management } & Age \\
\hline \multirow[t]{2}{*}{ Active management } & rho & -0.057 \\
\hline & $p$ & 0.1792 \\
\hline \multirow[t]{2}{*}{ Planning } & rho & -0.060 \\
\hline & $p$ & 0.1563 \\
\hline \multirow[t]{2}{*}{ Positive revaluation } & rho & -0.007 \\
\hline & $p$ & 0.8722 \\
\hline \multirow[t]{2}{*}{ Acceptance } & rho & -0.031 \\
\hline & $p$ & 0.4565 \\
\hline \multirow[t]{2}{*}{ Humour } & rho & 0.068 \\
\hline & $p$ & 0.1060 \\
\hline \multirow[t]{2}{*}{ Turning to religion } & rho & -0.060 \\
\hline & $p$ & 0.1523 \\
\hline \multirow[t]{2}{*}{ Seeking emotional support } & rho & -0.116 \\
\hline & $p$ & 0.0058 \\
\hline \multirow[t]{2}{*}{ Seeking instrumental support } & rho & -0.118 \\
\hline & $p$ & 0.0052 \\
\hline \multirow[t]{2}{*}{ Engaging in another activity } & rho & -0.041 \\
\hline & $p$ & 0.3328 \\
\hline \multirow[t]{2}{*}{ Denial } & rho & 0.033 \\
\hline & $p$ & 0.4343 \\
\hline \multirow[t]{2}{*}{ Venting off } & rho & 0.063 \\
\hline & $p$ & 0.1383 \\
\hline \multirow{2}{*}{$\begin{array}{l}\text { Use of psychoactive } \\
\text { substances }\end{array}$} & rho & 0.144 \\
\hline & $p$ & 0.0006 \\
\hline \multirow[t]{2}{*}{ Ceasing activity } & rho & 0.108 \\
\hline & $p$ & 0.0106 \\
\hline \multirow[t]{2}{*}{ Self-accusation } & rho & 0.022 \\
\hline & $p$ & 0.6073 \\
\hline
\end{tabular}

Spearman's rho correlation coefficient; $p$ - level of statistical significance $p=0.05$.

by older people. Younger people were more inclined to choose strategies associated with seeking support. Al-Dubai et al. showed that medical students adopted active coping strategies rather than avoidance [23]. Male students use active coping less, and alcohol or substance consumption more, than female students did. Older students used active coping, refraining, and planning more than younger students did. Żuralska et al. showed that in difficult situations nursery students more often that obstetrics students preferred a task-oriented approach and seeking social relations [24]. Whereas, midwives, as opposed to nurses, more 
Table 4. Stress coping strategies and the group of participants $(n=526)$

\begin{tabular}{|c|c|c|c|c|c|c|c|c|c|c|c|}
\hline \multirow[t]{2}{*}{ Group/strategies } & \multicolumn{2}{|c|}{ Nursing } & \multicolumn{2}{|c|}{ Obstetrics } & \multicolumn{2}{|c|}{ Medical rescue } & \multicolumn{2}{|c|}{ Physiotherapy } & \multicolumn{2}{|c|}{ Total } & \multirow[t]{2}{*}{$P$-value } \\
\hline & Mean & SD & Mean & SD & Mean & SD & Mean & SD & Mean & SD & \\
\hline Active management & 2.05 & 0.63 & 2.19 & 0.57 & 2.23 & 0.56 & 1.90 & 0.71 & 2.06 & 0.63 & 0.0052 \\
\hline Planning & 1.96 & 0.70 & 2.12 & 0.66 & 2.16 & 0.67 & 1.80 & 0.68 & 1.98 & 0.70 & 0.0022 \\
\hline Positive revaluation & 1.69 & 0.73 & 1.76 & 0.71 & 1.63 & 0.73 & 1.64 & 0.71 & 1.68 & 0.72 & 0.5621 \\
\hline Acceptance & 1.82 & 0.70 & 1.94 & 0.73 & 1.79 & 0.71 & 1.66 & 0.73 & 1.81 & 0.71 & 0.0605 \\
\hline Humour & 1.05 & 0.73 & 0.96 & 0.63 & 0.90 & 0.63 & 1.44 & 0.74 & 1.09 & 0.73 & $<0.0001$ \\
\hline Turning to religion & 1.30 & 0.97 & 1.43 & 0.99 & 0.93 & 1.00 & 1.46 & 0.74 & 1.31 & 0.95 & 0.0014 \\
\hline Seeking emotional support & 1.96 & 0.72 & 2.08 & 0.74 & 1.78 & 0.77 & 1.73 & 0.76 & 1.92 & 0.74 & 0.0042 \\
\hline Seeking instrumental support & 1.98 & 0.75 & 2.01 & 0.77 & 1.76 & 0.70 & 1.79 & 0.75 & 1.93 & 0.75 & 0.0117 \\
\hline $\begin{array}{l}\text { Getting engaged in another } \\
\text { activity }\end{array}$ & 1.72 & 0.74 & 1.76 & 0.71 & 1.52 & 0.84 & 1.62 & 0.77 & 1.69 & 0.76 & 0.2367 \\
\hline Denial & 0.87 & 0.76 & 0.68 & 0.68 & 0.44 & 0.61 & 1.33 & 0.78 & 0.88 & 0.78 & $<0.0001$ \\
\hline Venting off & 1.48 & 0.72 & 1.33 & 0.76 & 1.26 & 0.64 & 1.50 & 0.76 & 1.44 & 0.73 & 0.0687 \\
\hline Use of psychoactive substances & 0.46 & 0.73 & 0.38 & 0.65 & 0.56 & 0.66 & 1.00 & 0.83 & 0.56 & 0.76 & $<0.0001$ \\
\hline Ceasing activity & 0.80 & 0.70 & 0.69 & 0.65 & 0.65 & 0.61 & 1.35 & 0.72 & 0.87 & 0.72 & $<0.0001$ \\
\hline Self-accusation & 1.46 & 0.81 & 1.39 & 0.83 & 1.32 & 0.75 & 1.46 & 0.75 & 1.44 & 0.79 & 0.5350 \\
\hline
\end{tabular}

$S D$ - standard deviation, $p$ - level of statistical significance $p=0.05, n$ - number of subjects.

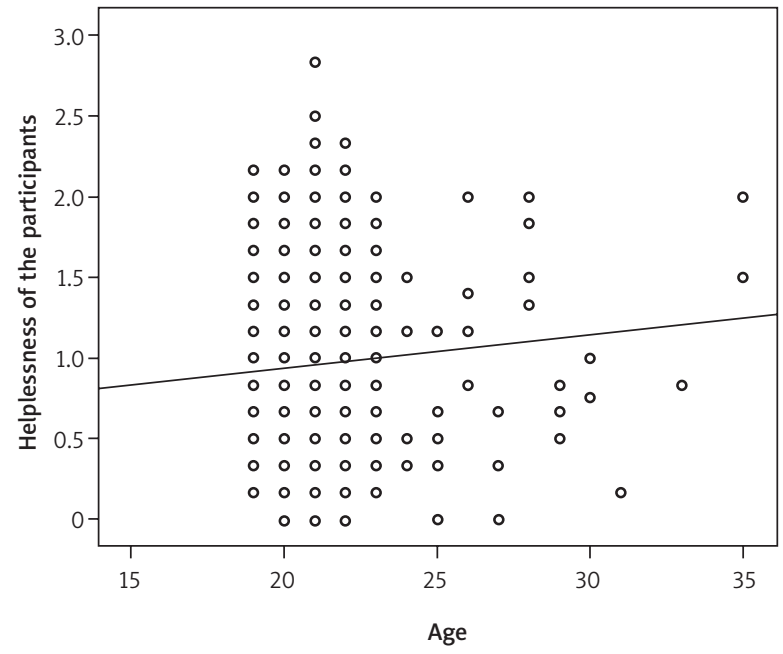

Figure 4. Age and helplessness of the participants

often preferred to apply an approach focused on emotions.

Okumura et al. and Hirsch et al. concluded that avoidance behaviours allow students to deal with stress in their relations with patients $[15,25]$. In our own research, students least often reached for psychoactive substances to deal with difficult situations. Similar results were obtained by Fornes-Vives et al. [26]. Using alcohol and smoking tobacco by medical

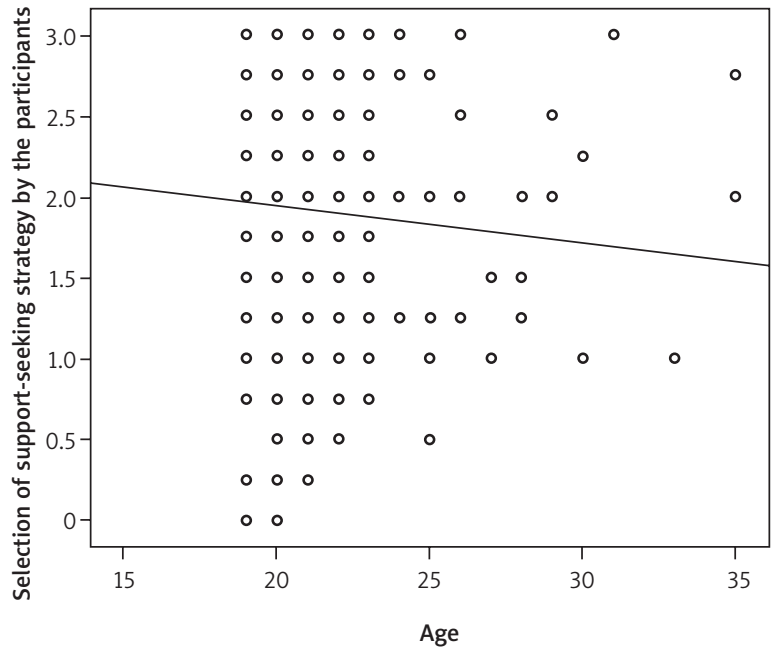

Figure 5. Age and selection of support-seeking strategy by the participants

students as a method of dealing with difficult situations was also confirmed by Ashton and Kamali [27].

Research by Bodys-Cupak et al. as well as that of Alzayyat and Al-Gamal also showed that students displaying avoidance behaviours experienced higher levels of stress than other participants $[3,5]$. Jałtuszewska et al. and Nowicki et al. showed that a task-oriented approach to dealing with stress is representative of paramedic students $[13,14]$. 
Table 5. General coping strategies and the group of participants $(n=526)$

\begin{tabular}{|c|c|c|c|c|c|c|c|c|c|c|c|}
\hline \multirow[t]{2}{*}{ Group } & \multicolumn{2}{|c|}{ Nursing } & \multicolumn{2}{|c|}{ Obstetrics } & \multicolumn{2}{|c|}{ Medical rescue } & \multicolumn{2}{|c|}{ Physiotherapy } & \multicolumn{2}{|c|}{ Total } & \multirow[t]{2}{*}{$P$-value } \\
\hline & Mean & SD & Mean & SD & Mean & SD & Mean & SD & Mean & SD & \\
\hline Active management & 1.90 & 0.53 & 2.02 & 0.52 & 2.01 & 0.47 & 1.78 & 0.53 & 1.91 & 0.53 & 0.0012 \\
\hline Helplessness & 0.91 & 0.54 & 0.82 & 0.52 & 0.84 & 0.42 & 1.27 & 0.55 & 0.95 & 0.55 & $<0.0001$ \\
\hline Seeking support & 1.97 & 0.67 & 2.05 & 0.68 & 1.77 & 0.68 & 1.76 & 0.66 & 1.92 & 0.68 & 0.0023 \\
\hline Avoidance behaviours & 1.36 & 0.54 & 1.26 & 0.53 & 1.07 & 0.48 & 1.48 & 0.54 & 1.34 & 0.54 & 0.0001 \\
\hline Acceptation & 1.82 & 0.70 & 1.94 & 0.73 & 1.79 & 0.71 & 1.66 & 0.73 & 1.81 & 0.71 & 0.0605 \\
\hline Humour & 1.05 & 0.73 & 0.96 & 0.63 & 0.90 & 0.63 & 1.44 & 0.74 & 1.09 & 0.73 & $<0.0001$ \\
\hline Turning to religion & 1.30 & 0.97 & 1.43 & 0.99 & 0.93 & 1.00 & 1.46 & 0.74 & 1.31 & 0.95 & 0.0014 \\
\hline
\end{tabular}

$S D$ - standard deviation, $p$ - level of statistical significance $p=0.05, n$ - number of subjects.

Table 6. Coping strategies and level of perceived stress in the participants $(n=526)$

\begin{tabular}{|c|c|c|c|c|c|c|c|c|c|}
\hline \multirow[t]{2}{*}{ PSS/Mini COPE } & \multicolumn{2}{|c|}{ Low level } & \multicolumn{2}{|c|}{ Average level } & \multicolumn{2}{|c|}{ High level } & \multicolumn{2}{|c|}{ Total } & \multirow[t]{2}{*}{$P$-value } \\
\hline & Mean & SD & Mean & SD & Mean & SD & Mean & SD & \\
\hline Active management & 2.30 & 0.59 & 2.06 & 0.63 & 1.97 & 0.63 & 2.06 & 0.63 & $<0.0001$ \\
\hline Planning & 2.25 & 0.65 & 1.94 & 0.67 & 1.88 & 0.71 & 1.98 & 0.70 & $<0.0001$ \\
\hline Positive revaluation & 2.03 & 0.65 & 1.68 & 0.72 & 1.54 & 0.70 & 1.68 & 0.72 & $<0.0001$ \\
\hline Acceptance & 2.07 & 0.66 & 1.76 & 0.71 & 1.73 & 0.71 & 1.81 & 0.71 & $<0.0001$ \\
\hline Humour & 1.08 & 0.71 & 1.14 & 0.68 & 1.06 & 0.76 & 1.09 & 0.73 & 0.4829 \\
\hline Turning to religion & 1.31 & 0.99 & 1.31 & 0.95 & 1.31 & 0.94 & 1.31 & 0.95 & 0.9886 \\
\hline Seeking emotional support & 2.08 & 0.67 & 1.86 & 0.69 & 1.89 & 0.79 & 1.92 & 0.74 & 0.0316 \\
\hline Seeking instrumental support & 2.02 & 0.71 & 1.91 & 0.75 & 1.90 & 0.76 & 1.93 & 0.75 & 0.4168 \\
\hline Getting engaged in another activity & 1.64 & 0.76 & 1.66 & 0.73 & 1.72 & 0.77 & 1.69 & 0.76 & 0.5063 \\
\hline Denial & 0.61 & 0.64 & 0.85 & 0.72 & 1.00 & 0.83 & 0.88 & 0.78 & 0.0001 \\
\hline Venting off & 1.26 & 0.68 & 1.37 & 0.74 & 1.56 & 0.72 & 1.44 & 0.73 & 0.0002 \\
\hline Use of psychoactive substances & 0.31 & 0.49 & 0.57 & 0.76 & 0.65 & 0.82 & 0.56 & 0.76 & 0.0007 \\
\hline Ceasing activity & 0.54 & 0.58 & 0.84 & 0.75 & 1.02 & 0.72 & 0.87 & 0.72 & $<0.0001$ \\
\hline Self-accusation & 1.11 & 0.69 & 1.38 & 0.74 & 1.61 & 0.82 & 1.44 & 0.79 & $<0.0001$ \\
\hline
\end{tabular}

$S D-$ standard deviation, $p$ - level of statistical significance $p=0.05, n-$ number of subjects.

Moreover, it was concluded that higher stress level is associated with an increase in interest in strategies based on denial, venting off, using psychoactive substances, refraining, and self-accusation. Similarly, Yildiz Findik et al. observed that stress levels were higher in nursing students manifesting passive coping strategies [28]. Results of research by Özdemir and Kaya showed that stress management strategies in students of nursing and obstetrics influenced their communication skills [29].

Our own research showed that over half of the participants experienced a high sense of self-efficacy. Older people had a weaker sense of self-efficacy than other participants. The sense of self-efficacy influenced the perception of a difficult situation and choice of strategy of stress management. The sense of self-efficacy in the Polish participants was a significant factor determining preferred stress management strategies [5]. People with a higher sense of self-efficacy experienced low levels of stress and significantly more often chose the following strategies in difficult situations: active management, planning, positive revaluation, acceptance, and seeking emotional support. Khater et al. claimed that appropriate levels of sense of self-efficacy in students may in practice help them in their practice in various clinical domains and to accept a demanding role [21].

The main limitation of this study is that data collection only occurred at one point in time, rather than longitudinally. Also, the participants in the study 
Table 7. Coping strategies and self-efficacy of the participants $(n=526)$

\begin{tabular}{|c|c|c|c|c|c|c|c|c|c|}
\hline \multirow[t]{2}{*}{ GSES/MiniCOPE } & \multicolumn{2}{|c|}{ Low level } & \multicolumn{2}{|c|}{ Average level } & \multicolumn{2}{|c|}{ High level } & \multicolumn{2}{|c|}{ Total } & \multirow[t]{2}{*}{$P$-value } \\
\hline & Mean & SD & Mean & SD & Mean & SD & Mean & SD & \\
\hline Active management & 1.56 & 0.66 & 1.99 & 0.52 & 2.20 & 0.64 & 2.06 & 0.63 & $<0.0001$ \\
\hline Planning & 1.59 & 0.60 & 1.89 & 0.63 & 2.10 & 0.72 & 1.98 & 0.70 & $<0.0001$ \\
\hline Positive revaluation & 1.37 & 0.76 & 1.54 & 0.65 & 1.83 & 0.72 & 1.68 & 0.72 & $<0.0001$ \\
\hline Acceptance & 1.55 & 0.78 & 1.67 & 0.68 & 1.94 & 0.69 & 1.81 & 0.71 & $<0.0001$ \\
\hline Humour & 0.98 & 0.80 & 1.05 & 0.71 & 1.13 & 0.72 & 1.09 & 0.73 & 0.1486 \\
\hline Turning to religion & 1.35 & 0.82 & 1.45 & 0.92 & 1.21 & 0.98 & 1.31 & 0.95 & 0.0149 \\
\hline Seeking emotional support & 1.73 & 0.80 & 1.91 & 0.74 & 1.96 & 0.73 & 1.92 & 0.74 & 0.0902 \\
\hline Seeking instrumental support & 1.75 & 0.73 & 1.98 & 0.76 & 1.93 & 0.74 & 1.93 & 0.75 & 0.1144 \\
\hline Getting engaged in another activity & 1.50 & 0.82 & 1.68 & 0.74 & 1.73 & 0.75 & 1.69 & 0.76 & 0.0968 \\
\hline Denial & 1.27 & 0.77 & 0.97 & 0.77 & 0.75 & 0.76 & 0.88 & 0.78 & $<0.0001$ \\
\hline Venting off & 1.61 & 0.69 & 1.48 & 0.69 & 1.38 & 0.75 & 1.44 & 0.73 & 0.0567 \\
\hline Use of psychoactive substances & 0.91 & 0.77 & 0.63 & 0.82 & 0.45 & 0.69 & 0.56 & 0.76 & $<0.0001$ \\
\hline Ceasing activity & 1.31 & 0.68 & 1.04 & 0.72 & 0.68 & 0.67 & 0.87 & 0.72 & $<0.0001$ \\
\hline Self-accusation & 1.80 & 0.79 & 1.54 & 0.79 & 1.31 & 0.77 & 1.44 & 0.79 & $<0.0001$ \\
\hline
\end{tabular}

$S D-$ standard deviation, $p$ - level of statistical significance $p=0.05$.

were mainly young women, which could potentially cause a bias. Further research that includes preceptors, staff nurses, and instructors is recommended in order to reveal the true image of the students' level of competences, and it should also be undertaken in multiple universities.

\section{Conclusions}

The level of sense of self-efficacy determines active stress management strategies in medical students exposed to stress. Almost half of the students experienced high levels of stress, and over half of them manifested high levels of self-efficacy.

The participants dealt with difficult situations mainly by active management, planning, and seeking instrumental support. In difficult situations, the paramedics and the midwives more often turned to active management than physiotherapists. Younger people were more inclined to choose strategies associated with seeking support. It was also shown that strategies of managing difficult situations based on helplessness were more often followed by older people.

This study indicates a need for stress management programmes in medical colleges. Educators need to provide appropriate support to students in both the clinical and academic environment. More studies are needed to identify and compare which interventions are effective in supporting students to cope with stress during their undergraduate education.

\section{Acknowledgments}

The authors would like to thank the students who took part in this study for their patience in answering the questionnaires.

\section{Conflict of interest}

The authors declare no conflict of interest.

\section{References}

1. Akhu-Zaheya LM, Shaban IA, Wejdan AK. Nursing students' perceived stress and influences in clinical performance. J Adv Nurs Stud 2015; 4: 44-48.

2. Kaneko S, Momino K. Stress factors and copin behaviors in nursing students during Fundamentals Clinical Training in Japan. Int J Nurs Clin Pract 2015; 2: 138-144.

3. Reeve K, Shumaker CJ, Yearwood EL, Crowell NA, Riley JB. Preceived stress and social suport in undergraduate nursing students` educational experiences. Nurse Educ Today 2013; 33: 419-424.

4. Wolf L, Stidham AW, Ross R. Predoctors of stress and coping strategies of US accelerated vs. generic baccalaureate nursing students: an embedded mixed methods study. Nurse Educ Today 2015; 35: 201-205.

5. Bodys-Cupak I, Majda A, Zalewska-Puchała J, Kamińska A. The impact of a sense of self-efficacy on the level of stress and the ways of coping with difficult situations in Polish nursing students. Nurse Educ Today 2016; 45: 102-107.

6. Grobecker PA. A sense of belonging and perceived stress among baccalaureate nursing students in clinical practice. Nurse Educ Today 2016; 29: 867-872. 
7. Cilingir D, Gursoy A, Hintistan S, Ozturk H. Nursing and midwifery college students` expectattions of their educators and perceived stressors during their education: a pilot study in Turkey. Int J Nurs Pract 2011; 17: 486-494.

8. Thomson D, Boyle D, Legg C, Owen M, Newman M, Cole MJ. Clinical placement: the perspectives of UK physioteraphy students on how prepared they were by their University for their first clinical placements: an example of one HEI. Int J Pract Based Learn Health Soc Care 2014; 2: 69-79.

9. Schiller JH, Stansfield RB, Belmonte DC, Purkiss JA, Reddy RM, House JB, Santen SA. Medical students` use of different coping strategies and relationship with academic performance in preclinical and clinical years. Teach Lear Med 2018; 30: 15-21.

10. Sand M, Hessam S, Sand D, Bechara FG, Vorstius C, Bromba M, Stockfleth E, Shiue I. Stress-coping styles of 459 emergency care physicians in Germany a pilot study. Anaesthesist 2016; 65: 841-846.

11. Janse van Vuuren EC, Bodenstein K, Nel M. Stressors and coping strategies among physiotherapy students: toward an integrated support structure. Health SA Gasondheid 2018; 23: a1091.

12. Shiferaw H, Anand S, Nemera G. Stress and coping strategies among generic B.Sc. nursing students of Jimma University, South West Ethiopia. Int J Recent Adv Multidiscip Res 2015; 2: 511-517.

13. Nowicki G, Ślusarska B, Jędrzejewicz D. Ways of coping with stress at paramedics work. Work Safety 2015; 8: 14-17.

14. Jałtuszewska S, Rut M, Rut A, Hebel K. Styles of coping with stress among paramedics and medical emergency students. Pomeran Life Sci 2017; 63: 62-66.

15. Okumura R, Suzuki T, Bai Y, Mukawa K. Stress coping ability in nursing students: studies on the influence factor of Sense of Coherence (SOC). Jpn Hosp 2012; 31: 71-79.

16. Juczyński Z, Ogińska Bulik N. Tools for measuring stress and coping with stress. Warsaw 2012.

17. Fernandes Pereira FG, Nunes Caldini L, Di Ciero M, Afio Caetano J. Assessment of stress in the inclusion of nursing students in hospital practice. Invest Educ Enferm 2014 32: 430-437.

18. Sun L, Gao J, Yang J, Zang XY, GangWang Y. The impact of professional identity on role stress in nursing students: a cross-sectional study. Int J Nurs Stud 2016; 63: 1-8.

19. Bodys-Cupak I, Majda A, Grochowska A, Zalewska-Puchała J, Kamińska A, Kuzera G. Patient-related stressors and coping strategies in baccalaureate nursing students during clinical practice. Med Stud 2019; 35: 41-47.

20. Kleiveland B, Natvig GK, Jepsen R. Stress, sense of coherence and quality of life among Norwegian nurse students after a period of clinical practice. Peer J 2015; 3: e1286.

21. Khater WA, Akhu-Zaheya LM, Shaban IA. Sources of stress and coping behaviours in clinical practice among baccalaureate nursing students. Int J Hum Soc Sci 2014; 4: 194-202.

22. Lachowska B, Szpringer M, Lachowski S, Porydzaj K. Conflict and facilitation between family and occupational roles versus work-related stress in the teachers' group. Med Stud 2018; 34: 41-56.

23. Al-Dubai SAR, Al-Naggar RA, Alshagga MA, Rampal KG. Stress and coping strategies of students in a Medical Faculty in Malaysia. Malaysian J Med Sci 2011; 18: 57-64.
24. Żuralska R, Majkowicz M, Gaworska-Krzemińska A. Psychological assessment of styles of coping with stress and personality traits of students of the Medical University of Gdansk. Probl Piel 2012; 20: 240-246.

25. Hirsch CD, Barlem ELD, Tomaschewski-Barlem JG, Figueira AB, Lunardi VL, Oliveira ACC. Predictors of stress and coping strategies adopted by nursing students. Acta Paul Enferm 2015; 28: 233-238.

26. Fornés-Vives J, Garcia-Banda G, Frias-Navarro D, RosalesViladrich G. Coping, stress, and personality in Spanish nursing students: a longitudinal study. Nurse Educ Today 2016; 36: 318-323

27. Ashton $\mathrm{CH}$, Kamali F. Personality, lifestyle, alcohol and drug consumption in a sample of British medical students. Med Educ 1995; 29: 87-192.

28. Yildiz Findik U, Ozbas A, Cavdar I, Yildizeli Topcu S, Onler E. Assessment of nursing students' stress levels and coping strategies in operating room practice. Nurse Educ Pract 2015; 15: 192-195.

29. Özdemir G, Kaya H. Midwifery and nursing students' communication skills and life orientation: correlation with stress coping approaches. Nurs Midwifery Stud 2013; 2: 198-205.

\section{Address for correspondence:}

\section{Iwona Bodys Cupak PhD}

Faculty of Health Sciences

Institute of Nursing and Midwifery

Jagiellonian University Medical College

ul. Michałowskiego 12, 31-126 Krakow, Poland

Phone: +48512396382

E-mail: i.bodys-cupak@uj.edu.pl 